\title{
MT-RNR1 Gene
}

National Cancer Institute

\section{Source}

National Cancer Institute. MT-RNR1 Gene. NCI Thesaurus. Code C128260.

This gene is involved in the translation of mitochondrial proteins and cellular metabolic processes. 